\title{
EFFECTS OF STARCH-GLYCEROL CONCENTRATION RATIO ON MECHANICAL AND THERMAL PROPERTIES OF CASSAVA STARCH-BASED BIOPLASTICS
}

\author{
Akbar Hanif Dawam Abdullah ${ }^{1}$, Oceu Dwi Putri ${ }^{1}$ and Winda Windi Sugandi ${ }^{2}$ \\ ${ }^{1}$ Research Unit for Clean Technology, Indonesian Institute of Sciences \\ Kampus LIPI Jalan Cisitu-Sangkuriang, Bandung, 40135 \\ ${ }^{2}$ Department of Physics, Sunan Gunung Djati State Islamic University \\ Jalan A.H. Nasution 105, Bandung, 40614 \\ E-mail: dawamdullah@yahoo.com
}

Received: 12 April 2019

Revised: 27 May 2019

Accepted: 28 June 2019

\begin{abstract}
EFFECTS OF STARCH-GLYCEROL CONCENTRATION RATIO ON MECHANICAL AND THERMAL PROPERTIES OF CASSAVA STARCH-BASED BIOPLASTICS. This study aimed to investigate the effects of different starch-glycerol concentration ratio on mechanical and thermal properties of cassava starch bioplastics. Bioplastics were prepared by mixing starch with glycerol at different starchglycerol w/w ratio $(2.5: 1,2.75: 1,3: 1$ and 3.5:1). Mechanical properties evaluated by measuring tensile strength and elongation at break where thermal properties waswere assessed by thermogravimetric analysis to determine the glass transition temperature $\left(T_{g}\right)$, melting temperature $\left(T_{m}\right)$ and melting enthalpy $\left(\Delta H_{m}\right)$ of bioplastics. Microstructure and chemical interactions in bioplastics were evaluated by SEM and FTIR. The surface hydrophobicity was determined by measuring the water contact angle. The increase of starch-glycerol concentration in bioplastics formed rough surface where the interaction of glycerol and starch molecules mainly occurred through hydrogen bonds. It also formed stronger and more rigid structure with the increase in tensile strength from $1.90 \mathrm{MPa}$ to $2.47 \mathrm{MPa}$ and the decrease in elongation at break from $8.55 \%$ to $5.92 \%$. Furthermore, the increase of starch-glycerol concentration increased $T_{g}$ from $37.5^{\circ} \mathrm{C}$ to $38.6^{\circ} \mathrm{C}, T_{m}$ from $96.3{ }^{\circ} \mathrm{C}$ to $120.7^{\circ} \mathrm{C}$ and $\Delta H_{m}$ from $100.4 \mathrm{~J} / \mathrm{g}$ to $155 \mathrm{~J} / \mathrm{g}$. Moreover, surface contact angle of bioplastics was increased from $40.6^{\circ}$ to $60.2^{\circ}$ with the increase of starch-glycerol concentration ratio.
\end{abstract}

Keywords: Bioplastic, Cassava Starch, Glycerol, Mechanical Properties, Thermal Properties.

\begin{abstract}
ABSTRAK
PENGARUH RASIO KONSENTRASI PATI-GLISEROL TERHADAP SIFAT MEKANIK DAN TERMAL BIOPLASTIK BERBASIS PATI SINGKONG. Penelitian ini bertujuan untuk mengetahui efek dari perbedaan rasio konsentrasi pati-gliserol terhadap sifat mekanik dan termal bioplastik pati singkong. Bioplastik dibuat dengan mencampurkan pati dengan gliserol pada perbandingan $\mathrm{b} / \mathrm{b}$ pati-gliserol yang berbeda $(2,5: 1$, 2,75: 1, 3: 1 dan 3,5:1). Sifat mekanik dievaluasi dengan mengukur kekuatan tarik dan perpanjangan putus, dimana sifat termal dinilai dengan analisis termogravimetri untuk menentukan suhu transisi gelas $\left(T_{g}\right)$, suhu leleh $\left(T_{m}\right)$ dan entalpi leleh $\left(\Delta H_{m}\right)$ bioplastik. Mikrostruktur dan interaksi kimia dalam bioplastik dievaluasi oleh SEM dan FTIR. Hidrofobisitas permukaan ditentukan dengan mengukur sudut kontak air. Peningkatan konsentrasi pati-gliserol dalam bioplastik membentuk permukaan yang kasar dimana interaksi antara gliserol dan molekul pati terjadi melalui ikatan hidrogen. Peningkatan konsentrasi pati-gliserol juga membentuk struktur yang lebih kuat dan lebih kaku dengan peningkatan kekuatan tarik dari 1,90 MPa menjadi 2,47 MPa dan penurunan perpanjangan putus dari $8,55 \%$ menjadi $5,92 \%$. Selain itu, peningkatan konsentrasi pati-gliserol meningkatkan $T_{g}$ dari $37,5^{\circ} \mathrm{C}$ menjadi $38,6^{\circ} \mathrm{C}, T_{m}$ dari $96,3{ }^{\circ} \mathrm{C}$ menjadi $120,7^{\circ} \mathrm{C}$ dan $\Delta H_{m}$ dari $100,4 \mathrm{~J} / \mathrm{g}$ menjadi $155 \mathrm{~J} / \mathrm{g}$. Sudut kontak permukaan bioplastik juga meningkat dari $40,6^{\circ}$ menjadi $60,2^{\circ}$ dengan meningkatnya rasio konsentrasi pati-gliserol.
\end{abstract}

Kata kunci: Bioplastik, Pati Singkong, Gliserol, Sifat Mekanik, Sifat Termal 


\section{INTRODUCTION}

The global production of bioplastics currently is approximately 750,000 tons/year which is relatively low in compared to petroleum-based conventional plastics with 200 million tons/year. Concerning the nature and environmental matters, the development of biodegradable plastics havehas been attracting immense attention in recent years with the purpose of reducing the environmental impact of plastics. Accordingly, natural polymers from agricultural products such as starch, cellulose, wood and sugar, are used as raw materials to fabricate bioplastics to cope with the environmental problems of petroleum-based plastics [1].

Starch, one of renewable and natural polymers, has been widely used to fabricate the biodegradable plastics which potentially replace the synthetic plastics for various applications in the last decades. This due to the noteworthy advantages of starch, such as low cost, abundant, edible and biodegradable. The diverse source of starch would result in various composition, shape, size and functionality of the semi-crystalline structure of starch [2]. Cassava, as one of the major resources of industrial starch, is extensively cultivated in most of tropical countries which make it affordable agricultural source of starch [3]. Nevertheless, compared to conventional synthetic plastics, starch-based bioplastics unveil several drawbacks by dint of its characteristic which is strong hydrophilic, poor mechanical and thermal properties, brittle and high moisture sensitivity. These shortcomings have to be overcome to increase the desirability of starch-based bioplastics in wide-ranging application [4,5]. Thus, the modification of starch-based bioplastics is necessary to overcome these shortcomings.

The addition of plasticizer is believed to be able to prevail the inherent disadvantages of starch-based bioplastics by reducing the intermolecular bonds and increasing the mobility of polymer chains. Moreover, the addition of plasticizer would decrease the glass transition temperature and improve the flexibility of starch-based bioplastics correspondingly [6]. Mali et al. [2] reported that glass transition temperature of bioplastics made from corn, cassava and yam starch with plasticizer and without plasticizer was different as well as their crystallinity and water vapor permeability due to the decrease or increase of glycerol content in bioplastics which affected the structure and mechanical properties of bioplastics. On the other hand, Parra et al. [3] added glutaraldehyde as crosslinking agent to the blend of cassava starch with glycerol and polyethylene glycol as plasticizer. The produced bioplastic exhibited good mechanical properties and low water permeability due to the crosslinking effect of glutaraldehyde. The addition of filler also could improve the properties of starch-based bioplastic. Cellulose nanofibers $(\mathrm{CN})$ as filler to the starch/polyvinyl alcohol (PVA) matrices enhanced the thermal stability about $100^{\circ} \mathrm{C}$. This study also revealed that addition of $4 \mathrm{wt} \% \mathrm{CN}$ could resist the hot water more than five hours [4]. Composite starch with $\varepsilon$-poly-L-lysine also showed higher tensile strength and elongation at break than that starch film alone. The composite also exhibited effective inhibition against Escherichia coli and Bacillus subtilis [5]. In spite of that, the study regarding influence of starch-plasticizer ratios of bioplastic produced by hot-pressing method on characteristic of starch-based bioplastic was scarcely found in the literature.

Therefore, in the present work, the effects of cassava starch-plasticizer ratios on the structural characteristic of the starch-based bioplastics and its correlation with the corresponding mechanical and thermal properties were investigated. Furthermore, the change of chemical properties and hydrophobicity of bioplastics was assessed correspondingly.

\section{EXPERIMENTAL METHOD}

\section{Materials}

Native starch was extracted from one variety of cassava cultivated in Bandung, Indonesia. Glycerol (99\% purity) was supplied by Merck (Darmstadt, Germany).

\section{Preparation of Cassava Starch and Bioplastics}

Cassava starch was extracted by method following the procedures of Daiuto et al. [7]. Cassava was washed, peeled and chopped into smaller pieces. Chopped cassava was then used for starch extraction in a ratio of $1: 4(\mathrm{w} / \mathrm{v})$ with distilled water by using a kitchen blender. The suspension was passed through a $0.25 \mathrm{~mm}$ sieve and was kept for $4 \mathrm{~h}$ for decantation. The supernatant liquid was removed and the precipitate was then passed through a $0.075 \mathrm{~mm}$ sieve. The slurry was stored again for $4 \mathrm{~h}$ and the upper layer was removed. The precipitate was then dried in an oven at $50{ }^{\circ} \mathrm{C}$ for $24 \mathrm{~h}$.

Bioplastics were prepared by mixing starch with glycerol using different starch-glycerol w/w ratio $(2.5: 1$, 2.75:1, 3:1 and 3.5:1) in a Phillips Blender HR2118/01. The mixtures were molded into iron molds of $20 \mathrm{~cm} \times 20$ $\mathrm{cm}$ and were heated in an oven at $50^{\circ} \mathrm{C}$ for $1.5 \mathrm{~h}$. The samples were cured subsequently by hot pressing in a hydraulic hot press at $135^{\circ} \mathrm{C}$ for 10 minutes under a load of $50 \mathrm{~kg} / \mathrm{cm}^{2}$. The samples then were stored at $25^{\circ} \mathrm{C}$ and $55 \pm 5 \% \mathrm{RH}$ for further characterization.

\section{Characterization of Bioplastics}

\section{Mechanical Properties of Bioplastics}

The tensile strength and elongation at break of bioplastics were measured on a universal testing machine 
(UCT-5T, Orientec Co. Ltd, Japan) as mean $\pm \mathrm{SD}(n=3)$ according to ASTM D882-12 with initial gauge separation and the crosshead speed were $100 \mathrm{~mm}$ and $50 \mathrm{~mm} / \mathrm{min}$, respectively.

\section{Thermal Properties of Bioplastics}

The effect of cassava starch-plasticizer ratios on thermal properties of bioplastics was determined by thermogravimetric analysis by using Netzsch DSC 214 Polyma (Selb, Germany). The samples with an average mass of $5 \mathrm{mg}$ was weighed in a standard aluminum pan. An unfilled pan was used as a reference. Both pans then were heated from $30^{\circ} \mathrm{C}$ to $200^{\circ} \mathrm{C}$ at a heating rate of 10 ${ }^{\circ} \mathrm{C} / \mathrm{min}$. The glass transition temperature $\left(T_{g}\right)$, melting temperature $\left(T_{m}\right)$, melting enthalpy $\left(\Delta H_{m}\right)$ were obtained by heating the samples at $40-500{ }^{\circ} \mathrm{C}$ with a heating rate of $10 \mathrm{~K} / \mathrm{min}$ under inert atmosphere $\left(\mathrm{N}_{2}\right.$ flow $\left.40 \mathrm{ml} / \mathrm{min}\right)$.

\section{Morphology of Bioplastics}

Surface and cross-section morphology of the bioplastics were observed by using a Jeol JSM-IT300 SEM (Tokyo, Japan). To avoid charging during the observation, the samples were coated with a thin layer of gold $(\sim 10 \mathrm{~nm})$ prior to SEM analysis. All samples were analyzed using an accelerating voltage of $20 \mathrm{kV}$.

\section{Chemical Interaction of Bioplastics}

Intermolecular interaction within bioplastics was examined using a Thermo Scientific Nicolet iS5 ATRFTIR spectrometer (Madison, WI, US) in a 4000-500 cm ${ }^{1}$ wave range with an average of 16 scans for spectrum integration and a scanning resolution of $4 \mathrm{~cm}^{-1}$.

\section{Surface Hydrophobicity of Bioplastics}

Surface hydrophobicity was assessed by means of contact angle measurement according to ASTM D5946-04. Water droplets $( \pm 5 \mu \mathrm{L})$ were dropped onto the bioplastics surface $(1 \mathrm{~cm} \times 1 \mathrm{~cm})$ in ambient condition. The measurement of three different spots on sample surface was carried out to determine the average static contact angle.

\section{RESULTS AND DISCUSSION}

\section{Mechanical Properties of Bioplastics}

The effect of different starch-glycerol ratio on the mechanical properties of cassava starch bioplastics is shown in Figure 1. The increase of starch concentration in bioplastics from 2.5:1 to 3.5:1 increased the tensile strength from 1.90 MPa to 2.47 MPa (Figure 1a). This result suggested that the strong hydrogen bonds formed by the starch-starch intermolecular interaction were more
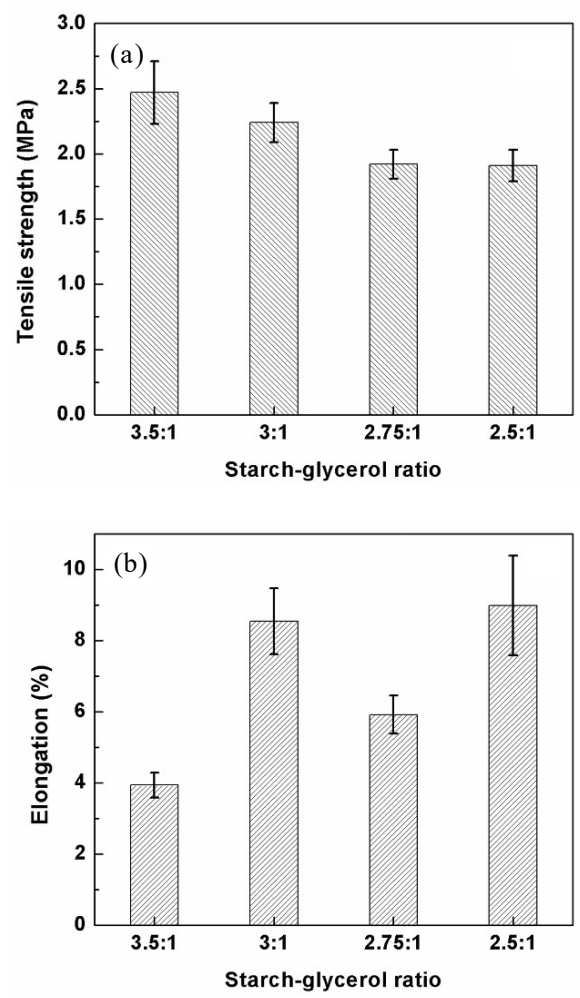

Figure 1. (a). Tensile strength and (b). elongation at break of cassava starch bioplastics with different starchglycerol concentration ratio.

dominant than starch-glycerol interaction [8]. When the concentration of glycerol in bioplastics was higher than that of starch, the role of glycerol that modified the functional properties of bioplastics by reducing the intermolecular interaction and increasing the polymer chains mobility was more dominant than the starchstarch intermolecular interaction [9]. Therefore, bioplastics with higher concentration of glycerol exhibited lower tensile strength but its flexibility and extensibility improved correspondingly.

In contrast, the elongation at break of bioplastics showed contrariwise. The increase of starch concentration in bioplastics from 2.5:1 to 3.5:1 decreased the elongation from $8.93 \%$ to $3.94 \%$. This might be because the intermolecular interaction between starchstarch molecules reduced the rigidity and promoted flexibility of bioplastics by providing more chain mobility [8]. Interestingly, the elongation of bioplastics decreased significantly from $8.55 \%$ to $5.92 \%$ when starch concentration ratio decreased from $3: 1$ to $2.75: 1$ (Figure 1b). This finding was reported by many authors [8,10-12] which might be caused by anti-plasticization behavior of glycerol. Anti-plasticization occurred when the plasticizer molecules increased beyond the critical value. This phenomenon was correlated with macromolecular mobility which was prevented by stronger interaction between plasticizer and starch molecules. Accordingly, the weaker interaction between starch molecules was occurred and the cohesive force 
of the polymer chains was decreased, leading to a decrease in elongation $[8,13]$. Otherwise, the reduction of elongation can be related to the phase separation caused by migration of glycerol from starch matrix. This migration restricted the mobility of starch chains and induced the reduction of the elongation. When the glycerol content was increase to the ratio of $2.5: 1$, the mobility of starch chains became facile once more and thus increased the elongation.

\section{Thermal Properties of Bioplastics}

Figure 2 shows the DSC curves of cassava starch bioplastics. The melting stage of the bioplastics was characterized by endothermic peaks in the DSC curves in the range of $60-180^{\circ} \mathrm{C}$ which specified to the melting temperature $\left(T_{m}\right)$ of the bioplastics. Transition glass temperature $\left(T_{g}\right), T_{m}$ and the melting enthalpy $\left(\Delta H_{m}\right)$ were obtained from DSC curves and tabulated in Table 1 . These endothermic peaks also indicated the semi-crystalline phase of the bioplastics. Both $T_{g}$ and $T_{m}$ were decreased with the decrease of the cassava starch-glycerol ratio. These results denoted the increase of deformation in the samples. That is to say, the addition of glycerol would modify the structure of starch network and transform the bioplastics to be less dense structure. Glycerol with the free low-molecular-weight chains would be distributed throughout the samples and increase the free volume. In consequent, the polymer chains that were in contact with glycerol would show faster dynamics than those within the polymer matrix, leading to the decrease in $T_{g}$ and $T_{m}$. This dynamics dependency on the temperature would result in more 'fragile' behavior due to the increase of the system free volume. Accordingly, the samples with low cassava starch-glycerol concentration ratio exhibited low tensile strength $[2,6,14-16]$.

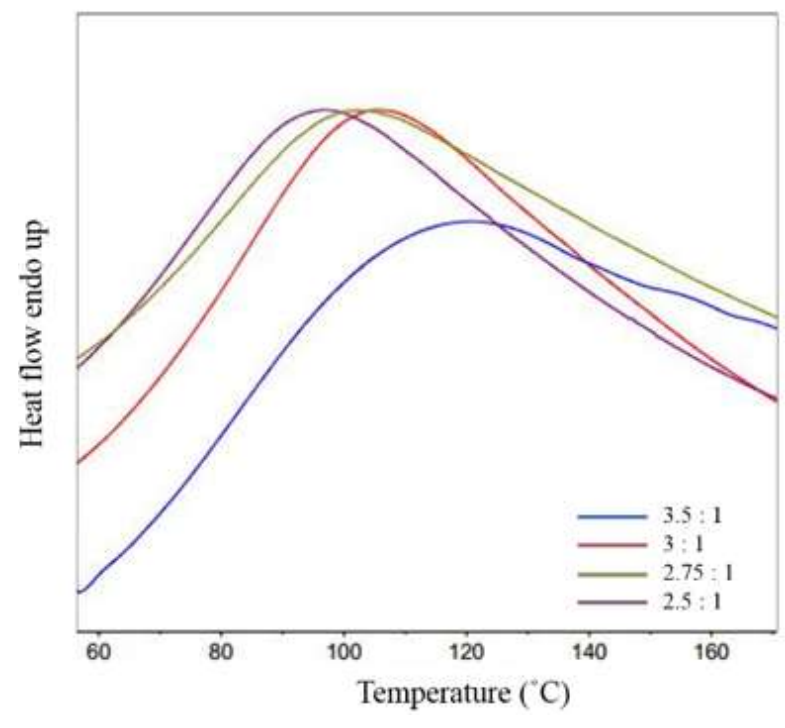

Figure 2. DSC thermograms of cassava starch bioplastics with different starch-glycerol concentration ratio.
The $\Delta H_{m}$ exhibited similar tendency with $T_{g}$ and $T_{m}$. As mentioned earlier, the increase of free volume as a result of the plasticizing effect of glycerol which deteriorated the intermolecular forces between polymer chains, would limit the growth and formation of crystals by hindering the arrangement and recrystallization of polymeric chains. Consequently, the less stable crystalline structure requiring less energy to melt would be formed in the case of samples with higher content of glycerol which caused the decrease of melting temperature and enthalpy of samples [17]. It is noteworthy that the $\Delta H_{m}$ was increased when the starchglycerol concentration was decreased from 3:1 to 2.75:1. As mentioned earlier, the anti-plasticizing behavior of glycerol might be responsible for this occurrence. The macromolecular mobility which was prevented by stronger interaction between plasticizer and starch molecules at critical extent of plasticizer would lead to the formation of stronger, more rigid and less extensible structure of bioplastics [8]. Consequently, more energy was required to melt this rigid structure which caused higher $\Delta H_{m}$.

\section{Microstructure and Chemical Interactions of Bioplastics}

Figure 3 shows the surface and cross-section morphology of cassava starch bioplastics. The starch granules were visible in high concentration ratio of starch-glycerol which indicated the incomplete gelatinization process. In high concentration of starch, the granules and crystalline structure of starch were difficult to be destroyed due to the increase in gelatinization temperatures, resulting in the rough surface. In contrast, the effective interaction between plasticizer molecules and starch was occurred at relatively low concentration ratio of starch-glycerol, leading to smoother surfaces [18-22]. The roughness value $(\mathrm{Ra})$ of bioplastic surface measured by using ImageJ software was presented in Table 1. This structural change was responsible for the change in mechanical properties of bioplastics. The rough surface showed by bioplastic with higher ratio of starch-glycerol demonstrated higher strength and stiffness. When the concentration of plasticizer in bioplastic was low, the free volume of starch macromolecules would be decreased and reinforced the interaction between polymer chains by promoting the macromolecular entanglement of starch, which resulted in the increase of strength and stiffness [23].

Figure 4 compares the FTIR spectra of cassava starch bioplastics with different starch-glycerol concentration ratio to investigate the chemical interactions between starch and glycerol. The bioplastics showed characteristic peaks at $3307 \mathrm{~cm}^{-1}$ (O-H stretching), $2928 \mathrm{~cm}^{-1}$ (C-H stretching), $1645 \mathrm{~cm}^{-1}(\delta(\mathrm{O}-\mathrm{H})$ bending of water), $1346 \mathrm{~cm}^{-1}\left(\mathrm{CH}_{2}\right), 1077 \mathrm{~cm}^{-1}$ (C-O-C bond stretching) 

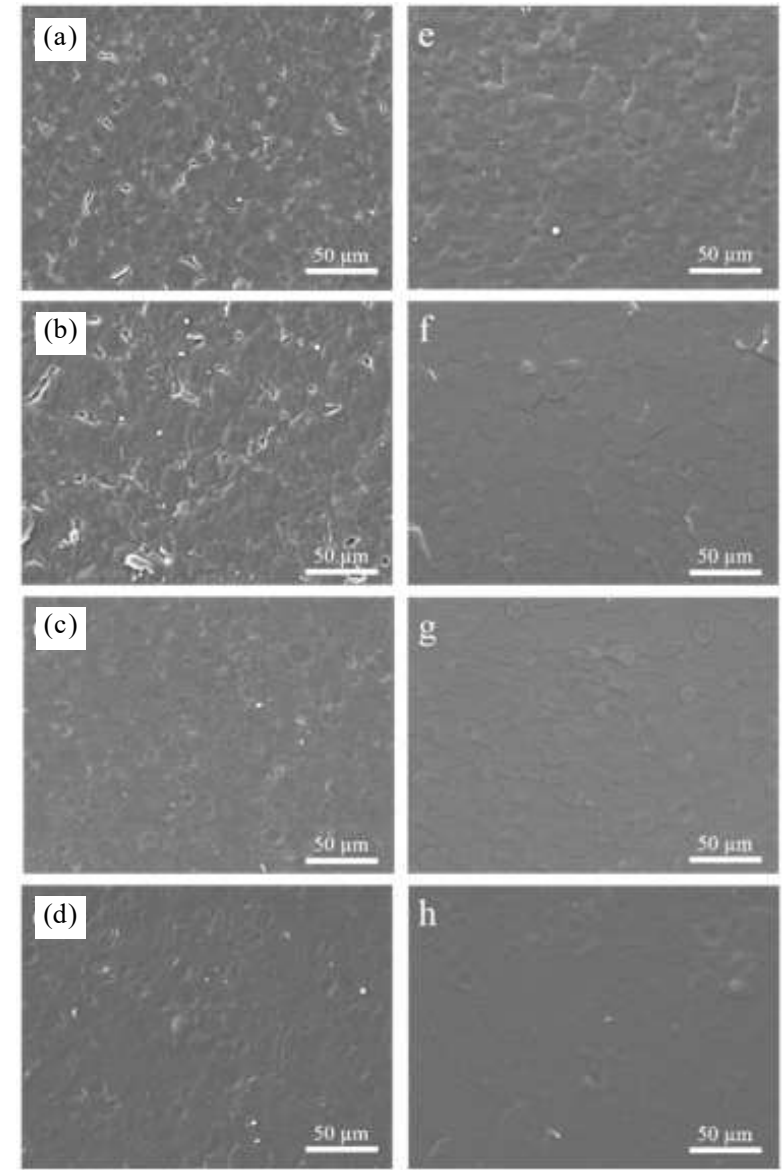

Figure 3. Surface (a-d) and cross-section (e-h) SEM micrographs of cassava starch bioplastics of (a, e) $3.5: 1$, (b, f) $3: 1,(c, g) 2.75: 1$, and (d, h) $2.5: 1$ starch-glycerol concentration ratio.

and $995 \mathrm{~cm}^{-1}$ (pyranose ring) [22-25]. With the increase of glycerol in the bioplastics, most of the characteristic peaks appeared at the same wavenumber. Interestingly, with the increase of glycerol, the $\mathrm{OH}$ peaks shifted to a higher wavenumber, indicating the weakening

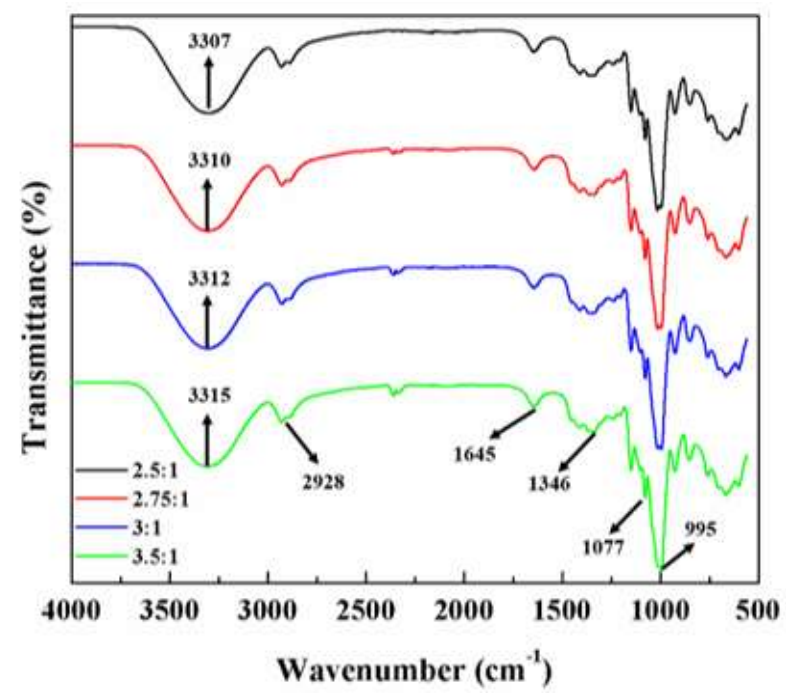

Figure 4. FTIR spectra of the cassava starch bioplastics with different starch-glycerol concentration ratio. of hydrogen bonds between starch molecules due to the formation of hydrogen bonds between some of starch molecules with glycerol [24]. In contrast, the C-O-H peak which corresponded to the crystalline of starch at 995 $\mathrm{cm}^{-1}$ exhibited higher intensity when concentration ratio of starch-glycerol was increased. This result indicated the increase of the crystalline part of starch after gelatinization which caused the improvement in mechanical properties of bioplastics [23].

\section{Hydrophobicity of Bioplastics}

To determine the hydrophobicity of cassava starch bioplastics, the measurement of water contact angle was conducted. In theory, the hydrophobic surface represented by the large contact angle and the hydrophilic surface represented by the small contact angle. In Table 1 , the large contact angle of $60.2^{\circ}$ was exhibited when the concentration ratio of starch-glycerol was 3.5:1. This result suggested that at low concentration of glycerol, the hydrophobicity of bioplastics was increased. Conversely, the small contact angle of $40.6^{\circ}$ was presented when the concentration ratio of starchglycerol was decreased to 2.5:1 which indicated the more hydrophilic behavior of bioplastics. This phenomenon was attributed to the hygroscopicity (water-binding capacity) of glycerol which caused the water molecules were more attracted to the surface of the bioplastics, resulting in the small contact angle. Nonetheless, the hydrophilicity of all samples was inevitable which indicated by the contact angle $<90^{\circ}$. It concluded that the bioplastics still could be wetted by water [26-29].

\section{CONCLUSION}

Cassava starch-based bioplastics were prepared using different starch-glycerol concentration ratio. The increase of starch-glycerol concentration ratio from 2.5:1 to 3.5:1 improved tensile strength and reduced elongation from $1.90 \mathrm{MPa}$ to $2.47 \mathrm{MPa}$ and $8.9 \%$ to $3.9 \%$,

Table 1. Contact angle and glass transition temperature, melting temperature and melting enthalpy of cassava starch bioplastics extracted from DSC curves.

\begin{tabular}{cccccc}
\hline Sample & $\begin{array}{c}\text { Roughness } \\
(\mu \mathrm{m})\end{array}$ & $\begin{array}{c}\text { Contact } \\
\text { angle }\left({ }^{\circ}\right)\end{array}$ & $\begin{array}{c}T_{g} \\
\left({ }^{\circ} \mathrm{C}\right)\end{array}$ & $\begin{array}{c}T_{m} \\
\left({ }^{\circ} \mathrm{C}\right)\end{array}$ & $\begin{array}{c}\Delta H_{m} \\
(\mathrm{~J} / g)\end{array}$ \\
\hline $3.5: 1$ & 10.81 & 60.2 & 38.6 & 120.7 & 155 \\
$3: 1$ & 11.68 & 59.2 & 37.9 & 105.6 & 134 \\
$2.75: 1$ & 9.13 & 54.6 & 37.6 & 103.7 & 155.9 \\
$2.5: 1$ & 8.98 & 40.6 & 37.5 & 96.3 & 100.4 \\
\hline
\end{tabular}

respectively. Moreover, the increase of starch-glycerol concentration ratio would also increase the glass transition temperature from $37.5^{\circ} \mathrm{C}$ to $38.6^{\circ} \mathrm{C}$, melting temperature from $96.3^{\circ} \mathrm{C}$ to $120.7^{\circ} \mathrm{C}$ and melting enthalpy of bioplastics from $100.4 \mathrm{~J} / \mathrm{g}$ to $155 \mathrm{~J} / \mathrm{g}$. SEM micrographs showed that the increase of glycerol content in the bioplastics formed smoother surface which indicated the stronger interaction between starch and glycerol where 
the intermolecular interaction mainly involved the $-\mathrm{OH}$ group through hydrogen bond. In addition, different starch-glycerol concentration ratio also ehangechanges the hydrophobicity of bioplastics where surface contact angle of bioplastics increased with the increase of starchglycerol concentration ratio from $40.6^{\circ}$ to $60.2^{\circ}$.

\section{ACKNOWLEDGMENT}

This work was supported by Ministry of Research, Technology and Higher Education of the Republic of Indonesia, Insinas Project fiscal year 2018 with grant number of 38/P/RPL-LIPI/INSINAS-1/III/2018.

\section{REFERENCES}

[1]. F. Gironi and V. Piemonte, "Bioplastics and Petroleum-based Plastics: Strengths and Weaknesses," Energy Sources, Part A: Recovery, Utilization, and Environmental Effects, vol. 33, no. 21,pp. 1949-1959, 2011.

[2]. S. Mali, M. V. E. Grossmann, M. A. García, M. N. Martino, and N. E. Zaritzky, "Effects of controlled storage on thermal, mechanical and barrier properties of plasticized films from different starch sources," Journal of Food Engineering, vol. 75, no. 4, pp. 453-460, 2006.

[3]. D. Parra, C. Tadini, P. Ponce, and A. Lugao, "Mechanical properties and water vapor transmission in some blends of cassava starch edible films," Carbohydrate Polymers, vol. 58, no. 4, pp. 475-481, 2004.

[4]. A. N. Frone, C. A. Nicolae, R. A. Gabor, and D. M. Panaitescu, "Thermal properties of water-resistant starch - polyvinyl alcohol fitlatin/potato starch edible biocomposite films: Correlation between morphology and physical properties," Carbohydrate Polymers, vol. 157, pp. 1162-1172, 2017.

[16]. C. Zhi, Y. Bando, C. Tang, H. Kuwahara, and D. Golberg, "Large-Scale Fabrication of Boron Nitride Nanosheets and Their Utilization in Polymeric Composites with Improved Thermal and Mechanical Properties," Advanced Materials, vol. 21, no. 28, pp. 2889-2893, 2009.

[17]. C. M. Jaramillo, T. J. Gutiérrez, S. Goyanes, C. Bernal, and L. Famá, "Biodegradability and plasticizing effect of yerba mate extract on cassava starch edible films," Carbohydrate Polymers, vol. 151,pp. 150-159, 2016.

[18]. G. G, F. P, C. C, and G. A, "Gluten free Maize Cookies Prepared with High-amylose Starch: In Vitro Starch Digestibility and Sensory Characteristics," Journal of Nutrition \& Food Sciences, vol. 05, no. 06, 2015.
[19]. S. C. Lara and F. Salcedo, "Gelatinization and retrogradation phenomena in starch/ montmorillonite nanocomposites plasticized with different glycerol/water ratios," Carbohydrate Polymers, vol. 151,pp. 206-212, 2016.

[20]. Z. Li, W. Liu, Z. Gu, C. Li, Y. Hong, and L. Cheng, "The effect of starch concentration on the gelatinization and liquefaction of corn starch," Food Hydrocolloids, vol. 48, pp. 189-196, 2015.

[21]. H. Niu, M. Zhang, X. Xia, Q. Liu, and B. Kong, "Effect of porcine plasma protein hydrolysates on long-term retrogradation of corn starch," Food Chemistry, vol. 239, pp. 172-179, 2018.

[22]. M. L. Sanyang, S. M. Sapuan, M. Jawaid, M. R. Ishak, and J. Sahari, "Effect of plasticizer type and concentration on physical properties of biodegradable films based on sugar palm (arenga pinnata) starch for food packaging," Journal of Food Science and Technology, vol. 53, no. 1, pp. 326-336, 2015.

[23]. A. H. D. Abdullah, S. Pudjiraharti, M. Karina, O. D. Putri, and R. H. Fauziyyah, "Fabrication and Characterization of Sweet Potato StarchbasedBioplastics Plasticized with Glycerol," Journal of Biological Sciences, vol. 19, no. 1, pp. 57-64, 2019.

[24]. K. M. Dang and R. Yoksan, "Development of thermoplastic starch blown film by incorporating plasticized chitosan," Carbohydrate Polymers, vol. 115, pp. 575-581, 2015.

[25]. J. Sahari, S. Sapuan, E. Zainudin, and M. Maleque, "Physico-chemical and Thermal Properties of Starch Derived from Sugar Palm Tree (Arenga pinnata)," Asian Journal of Chemistry, vol. 26, no. 4,pp. 955-959, 2014.

[26]. C. Bangyekan, D. Aht-Ong, and K. Srikulkit, "Preparation and properties evaluation of chitosancoated cassava starch films," Carbohydrate Polymers, vol. 63, no. 1, pp. 61-71, 2006.

[27]. M. Jouki, N. Khazaei, M. Ghasemlou, and M. Hadinezhad, "Effect of glycerol concentration on edible film production from cress seed carbohydrate gum," Carbohydrate Polymers, vol. 96, no. 1, pp. 39-46, 2013.

[28]. S. M. A. Razavi, A. M. Amini, and Y. Zahedi, "Characterisation of a new biodegradable edible film based on sage seed gum: Influence of plasticiser type and concentration," Food Hydrocolloids, vol. 43, pp. 290-298, 2015.

[29]. S. Seyedi, A. Koocheki, M. Mohebbi, and Y. Zahedi, "Lepidium perfoliatum seed gum: A new source of carbohydrate to make a biodegradable film," Carbohydrate Polymers, vol. 101, pp. 349358, 2014. 